\title{
Multivariate approach to determination of intermediate target of monetary policy strategy in CEE countries
}

\author{
Mario Pečarić ${ }^{1}$, Snježana Pivac ${ }^{1, *}$ and Josip Visković ${ }^{1}$ \\ ${ }^{1}$ Faculty of Economics, University of Split \\ Cvite Fiskovića 5, 21000 Split, Croatia \\ E-mail: 〈\{mpecaric,spivac, josip.viskovic\}@efst.hr $\rangle$
}

\begin{abstract}
The main aim of this paper is to investigate the characteristics of Central and East European (CEE) countries considering their choice of an intermediate target of the monetary policy strategy. A theoretical choice of the intermediate target of the monetary policy strategy refers to inflation targeting, exchange rate targeting and monetary targeting, with the latter not being a practical choice in these countries. This research tends to find out whether this choice means different economic characteristics considering macroeconomic and financial variables, and whether the choice of an individual intermediate target implies better overall economic performance. Eleven characteristics are classified for 14 chosen CEE countries, using the multivariate and multicriteria approaches. The research was conducted in four years $(2005,2007,2009$ and 2011) in order to see whether performance and ranking of countries change when taking into account the financial crisis. The results show that, when considering all 11 indicators, countries cannot be classified into two equal clusters considering the choice of the intermediate target. However, when clustering is done using foreign currency denominated loans and three forms of central bank independence, results show that countries are clustered according to our expectations, i.e., foreign currency denominated loans and two forms of central bank independence contribute to a difference between countries. Furthermore, countries were ranked considering overall economic performance, but no significant difference considering the choice of the intermediate target was found.
\end{abstract}

Key words: multivariate and multicriteria approaches, choice of intermediate target, characteristics of CEE countries

Received: October 3, 2014; accepted: December 2, 2014; available online: December 30, 2014

\section{Introduction}

Intermediate target serves as a nominal anchor for monetary policy and tends to resolve the problem of time-lag in conducting monetary policy by which a central bank accomplishes and maintains its ultimate goal of monetary policy. The theoretical choice refers to inflation targeting, exchange rate targeting and monetary targeting. However, neither all intermediate targets are recommended

${ }^{*}$ Corresponding author. 
for each country nor all of them have the same consequences once they are implemented. Therefore, the aim of this paper is to find out whether a practical choice of the intermediate target is in line with theoretical background considering 11 selected economic indicators in CEE countries. These countries, as small open economies that were/are on their way to economic integration with the EU, exhibit two types of intermediate targets - inflation targeting and exchange rate targeting. Accordingly, the aim is to find out whether these two intermediate targets are connected with different CEE countries characteristics, i.e., to find out which of these 11 characteristics contribute to the difference between clusters considering the intermediate target. Also, the world is still fighting the consequences of the recent financial crisis, which has revealed the flaws of some intermediate targets. Thus, an additional aim is to find out whether the selected characteristics have changed for CEE countries during the financial crisis (2009 and 2011) in comparison to the period before the crisis (2005 and 2007). Previous research was based on the adequacy of the intermediate target's choice for particular countries ([3], [4], [10]), but not on the connection between the choice and the economic performance of the countries, especially in CEE countries. Moreover, interrelation between the choice of the intermediate target and performance was not previously done using multivariate analysis.

Due to the fact that multivariate analysis is based on the statistical principle of multivariate statistics which involves observation and analysis of more than one statistical variable at a time, multivariate analysis is considered as an adequate method for this type of research. Furthermore, multivariate analysis examines interdependencies and group variables and/or grouping of cases according to their similarity, e.g., connections (cluster analysis).

The rest of the paper is organized as follows. Section 2 provides a theoretical background of the relationship between the choice of intermediate targets and selected characteristics. Section 3 presents research methods and results. At the end of the paper, concluding remarks of the study are presented.

\section{The country's economic characteristics and the choice of the intermediate target of monetary policy}

Intermediate target is defined as an economic variable (i) which the central bank can control with a certain lag and a certain degree of accuracy and (ii) which is relatively stable or at least predictably connected with the ultimate goal of monetary policy. Moreover, the intermediate target increases the effectiveness of monetary policy in achieving the final goals. Besides, the choice also defines the exchange rate regime of the country and freedom of monetary policy. Namely, the countries that have an inflation targeting strategy allow a more flexible exchange rate and monetary policy. This choice further determines features of the country, especially during a financial crisis. 
Inflation targeting is a relatively new monetary policy strategy whose number grew to over 50 countries in 2000 [9], with the global share of countries that target inflation in 2005 over $55 \%$ [13]. A growing number of countries have adopted the inflation targeting strategy in the nineties and this increased tendency was due to failure of other nominal anchors to contain inflation in both developed and developing countries [15]. The share of countries that target the exchange rate in 2000 was approximately 30\%, mainly characterizing developing countries that have fixed their currency. Targeting monetary aggregates fell to approximately less than 10\% [13]. These global trends can also be recognized in CEE countries. Specifically, according to data for 2010, seven sample countries have an inflation and seven an exchange rate targeting strategy. Therefore, this paper will focus on these two strategies.

In the next section, a relationship between the choice of the intermediate target and the following characteristics, i.e., variables, will be discussed: GDP level, inflation, external debt, foreign currency denominated loans, central bank independence, level of banking sector loans, international reserves, interest rates, trade openness, government budget deficit and capital openness.

GDP level, as a common measure of economic development, expressed as GDP $\mathrm{p} / \mathrm{c}$ is expected to be more prone to inflation targeting countries. GDP level implies a more developed financial system as a prerequisite for implementing a more sophisticated monetary strategy. Therefore, more developed countries are prone to an inflation targeting strategy. Still, due to a relatively homogenous group of selected countries, some other indicators might be crucial in the choice of a nominal anchor; thus, the level of economic development might not be a significant variable.

Regarding the level of the consumer price index, both strategies have a tendency to low and stable inflation. The aim of inflation targeting is to diminish inflation expectations and bring low and stable inflation. The exchange rate targeting strategy is mainly used as a nominal anchor for price stability, i.e., these countries practically "import" price stability from a pegged country and the exchange rate serves as a credible monetary anchor diminishing inflation expectations. Countries that were not targeting inflation achieved equal, if not better results in terms of price stability [2]. This means that there should not be any difference in the inflation level considering the choice of the intermediate target.

In countries that chose the exchange rate strategy, a domestic interest rate is determined by an anchor country interest rate. Considering the inflation targeting countries, the interest rate is the main instrument in achieving price stability and it is expected to show relatively often usage and possible higher interest rate volatility. Still, all selected countries, despite the nominal anchor strategy, are characterized by country risk premium and therefore interest rates 
are not expected to be significantly different. High trade openness is characteristic of small open economies, so it is expected that these economies prefer fixed exchange rate regimes which reduce transaction costs and currency risk as well as encourage capital inflows. However, all selected countries have a high level of trade openness.

It should be taken into consideration that all selected countries have liberalized, more or less, their capital accounts (capital openness should therefore be similar) and have witnessed great capital inflows during the last decade indebting themselves abroad. The result of this process is a high level of external debt which might be characteristic of all countries. But, due to real exchange rate appreciation, i.e., the deficit of current account balance, in the case of exchange rate targeting countries, it would be expected that these countries witness significant external debt growth. As a result of great inflows, a high level of banking loans in both groups of countries is expected, i.e., similar levels of the ratio of private sector credit to GDP.

In order to be able to maintain the stability of the exchange rate of domestic currency, countries that target the exchange rate are expected to have a higher level of international reserves. This does not mean that inflation targeting countries do not hold adequate levels of international reserves, but a more active approach in managing currency risk is expected. Due to high inflation, monetary policy credibility deficit and high devaluation of domestic currency in history, companies and households in these countries are prone to place their savings in foreign currency resulting in high deposit eurization. The consequence is that loans are then also denominated in foreign currency resulting in a high level of foreign currency loans or foreign currency denominated loans, especially in exchange rate targeting countries [17]. Therefore, foreign currency denominated loans (eurization) should characterize exchange rate countries.

Because of more rigid exchange rate regimes used in exchange rate targeting countries, mainly based on rules, it is expected that these countries have higher de iure central bank independence [17]. On the other hand, due to complexity of monetary policy management, in terms of instruments and goals [11], higher de facto central bank independence is expected in inflation targeting countries. Finally, one of the assumptions of inflation targeting is that fiscal policy must be reliable, [12]. But fiscal discipline is necessary for exchange rate targeting too, aiming to sustain a fixed exchange rate regime in a longer period. A lack of active monetary policy in the latter countries is theoretically expected to be compensated by expansive fiscal policy, i.e., budget deficit policy. During a financial crisis, both types of targeting are prone to budget deficit.

Generally, cluster analysis is not expected to cluster countries considering the intermediate target when all selected variables are taken into account. However, our aim is to find out which of these 11 variables contribute to 
clustering, i.e., whether these are, regarding the theoretical background and a selected sample, foreign currency loans, central bank independence and external debt.

\section{Methods and results}

According to the theoretical background, multivariate and multicriteria analysis are used in order to cluster and rank a selected sample of countries into two groups considering selected variables [14]. In this section, methods used will be presented, a selected sample explained and variables and research results presented.

Multivariate analysis (MVA) is based on the statistical principle of multivariate statistics, which involves observation and analysis of more than one statistical variable at a time. Clustering is a type of multivariate statistical analysis also known as cluster analysis, unsupervised classification analysis, or numerical taxonomy. It is based on a mathematical formulation of a measure of similarity. The term cluster analysis [1] encompasses a number of different algorithms and methods for grouping objects of similar kind into respective categories. Use of different distance metrics for measuring distances between clusters may generate different results. Performing multiple experiments and comparing the results is recommended to support the veracity of the original results. The most common distance measurements between data points are the Euclidean distance and the Euclidean squared distance. Cluster analysis does not presuppose any statistical significance, and it is therefore recommended to use appropriate statistical tests in practical analyses [16].

\subsection{Data description}

To find out macroeconomic and financial variables that contribute to the difference between countries considering their intermediate target, data on the following $14 \mathrm{CEE}$ countries are considered: Albania, Bosnia and Herzegovina, Bulgaria, Croatia, the Czech Republic, Estonia, Latvia, Lithuania, Hungary, Macedonia, Moldavia, Poland, Romania and Turkey. Selected variables are expressed as follows: (i) economic development as GDP per capita; (ii) inflation as a consumer price index; (iii) external debt to GDP ratio; (iv) FC loans to total loans (due to the Estonian approach to the EMU, data from 2010 is used for 2011); (v) central bank independence (due to data unavailability, data from 2009 are used for 2011) is divided into three categories of independence Political and Legal (PLCBI), Governance and Conduct of Monetary Policy (CBGCMP) and Transparency and Accountability (CBTA) [8]; (vi) the level of domestic credit to the private sector, (vii) the ratio of international reserves to imports, (viii) interest rates as lending interest rates (due to data availability, 
an average interest rate excluding interest rates on overdraft and revolving credit for Poland and an average interest rate on loans in $\$, €$ and Turkish lira is used for Turkey), (ix) trade openness as the ratio of a sum of export and import to GDP, (x) government fiscal policy as government budget deficit to GDP and (xi) capital openness, as in [7]. The data are taken from the World Bank database and from the European Bank for Reconstruction and Development database, as well as from mecometer.com. All data refer to years 2005, 2007, 2009 and 2011. The data for CBI indices is taken from [8], the data for capital openness from [7], while the intermediate target is defined by authors.

\subsection{Research results}

\subsubsection{Multivariate analysis}

Research was done in two steps. Firstly, countries were clustered using all selected variables, and in the second step only those variables were considered that were least important in first cluster. Results of first clustering are presented in Tables 1 and 2. As Table 1 shows, clusters are mainly formed by the level of economic development. Considering all indicators, all cluster 1 countries are ranked in worse economic positions in comparison to cluster 2. These results are in line with the results of the ranking multicriteria PROMETHEE method (Section 3.2.2.). However, cluster analysis does not divide countries considering the intermediate target, i.e., CEE countries are quite similarly presented in each cluster. This is in line with expectations that some variables might not be significant characteristics in differing countries considering the intermediate target.

\begin{tabular}{|c|c|c|}
\hline Years & Clusters & $\begin{array}{l}\text { Number of countries with the } \\
\text { appropriate intermediate target: }\end{array}$ \\
\hline \multirow{4}{*}{ 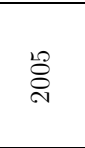 } & \multirow{2}{*}{$\begin{array}{l}\text { Cluster 1: Albania, Bosnia, Bulgaria, Latvia, } \\
\text { Macedonia, Moldova, Romania, Turkey }\end{array}$} & -inflation targeting (3) \\
\hline & & -exchange rate targeting (5) \\
\hline & \multirow{2}{*}{$\begin{array}{l}\text { Cluster 2: Croatia, Czech Republic, Estonia, } \\
\text { Hungary, Lithuania, Poland }\end{array}$} & -inflation targeting (2) \\
\hline & & -exchange rate targeting (4) \\
\hline \multirow{4}{*}{$\stackrel{\overbrace{}}{\circ}$} & \multirow{2}{*}{$\begin{array}{l}\text { Cluster 1: Albania, Bosnia, Bulgaria, Macedonia, } \\
\text { Moldova, Romania, Turkey }\end{array}$} & -inflation targeting (3) \\
\hline & & -exchange rate targeting (4) \\
\hline & \multirow{2}{*}{$\begin{array}{l}\text { Cluster 2: Croatia, Czech Republic, Estonia, } \\
\text { Lithuania, Hungary, Latvia, Poland }\end{array}$} & -inflation targeting (5) \\
\hline & & -exchange rate targeting (2) \\
\hline \multirow{4}{*}{ 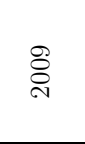 } & \multirow{2}{*}{$\begin{array}{l}\text { Cluster 1: Albania, Bosnia, Bulgaria, Macedonia, } \\
\text { Moldova, Romania, Turkey }\end{array}$} & -inflation targeting (4) \\
\hline & & -exchange rate targeting (3) \\
\hline & \multirow{2}{*}{$\begin{array}{l}\text { Cluster 2: Croatia, Czech Republic, Estonia, } \\
\text { Hungary, Latvia, Lithuania, Poland }\end{array}$} & -inflation targeting (3) \\
\hline & & -exchange rate targeting (4) \\
\hline \multirow{4}{*}{$\underset{\sim}{\rightleftharpoons}$} & \multirow{2}{*}{$\begin{array}{l}\text { Cluster 1: Albania, Bosnia, Bulgaria, Macedonia, } \\
\text { Moldova, Romania, Turkey }\end{array}$} & -inflation targeting (4) \\
\hline & & -exchange rate targeting (3) \\
\hline & \multirow{2}{*}{$\begin{array}{l}\text { Cluster 2: Croatia, Czech Republic, Estonia, } \\
\text { Hungary, Latvia, Lithuania, Poland }\end{array}$} & -inflation targeting (3) \\
\hline & & -exchange rate targeting (4) \\
\hline
\end{tabular}

Table 1: Classification of countries using the non-hierarchical $k$-means cluster method according to all selected criteria 
CEE countries

Furthermore, as Table 2 shows, economic development (GDP p/c), domestic credit to the private sector and the capital openness index contribute to the difference between clusters in each selected year (bolded p-values), while the intermediate target, foreign currency denominated loans and three forms of central bank independence do not contribute to the difference in either year. Other indicators were significant mainly in three years (external debt, international reserves, lending interest rates and trade openness), while inflation contributed to the difference in two years.

\begin{tabular}{|l|r|r|r|r|}
\hline \multirow{2}{*}{ Criteria $^{\mathrm{ii}}$} & \multicolumn{4}{|c|}{ F test ${ }^{\mathrm{i}} \mathrm{p}$-value } \\
\cline { 2 - 5 } & \multicolumn{1}{|c|}{2005} & \multicolumn{1}{|c|}{2007} & \multicolumn{1}{c|}{2009} & \multicolumn{1}{c|}{2011} \\
\hline C0 & 0.867 & 0.317 & 0.626 & 0.626 \\
\hline C1 & $<\mathbf{0 . 0 0 1}$ & $<\mathbf{0 . 0 0 1}$ & $<\mathbf{0 . 0 0 0}$ & $<\mathbf{0 . 0 0 0}$ \\
\hline C2 & $\mathbf{0 . 1 4 6}$ & 0.861 & 0.685 & $\mathbf{0 . 1 0 2}$ \\
\hline C3 & 0.237 & $\mathbf{0 . 0 3 0}$ & $\mathbf{0 . 0 8 8}$ & $\mathbf{0 . 0 5 6}$ \\
\hline C4 & 0.681 & 0.631 & 0.574 & 0.513 \\
\hline C5a & 0.893 & 0.906 & 0.906 & 0.906 \\
\hline C5b & 0.831 & 0.959 & 0.959 & 0.959 \\
\hline C5c & 0.865 & 0.346 & 0.346 & 0.346 \\
\hline C6 & $\mathbf{0 . 1 4 2}$ & $\mathbf{0 . 0 0 7}$ & $\mathbf{0 . 0 0 8}$ & $\mathbf{0 . 0 0 5}$ \\
\hline C7 & $\mathbf{0 . 0 6 7}$ & $\mathbf{0 . 0 0 4}$ & 0.255 & $\mathbf{0 . 1 8 1}$ \\
\hline C8 & $\mathbf{0 . 0 6 1}$ & $\mathbf{0 . 0 2 7}$ & 0.327 & $\mathbf{0 . 0 0 5}$ \\
\hline C9 & $\mathbf{0 . 0 6 9}$ & 0.404 & $\mathbf{0 . 1 5 0}$ & $\mathbf{0 . 0 8 1}$ \\
\hline C10 & $\mathbf{0 . 1 8 6}$ & 0.664 & 0.903 & 0.894 \\
\hline C11 & $\mathbf{0 . 0 7 3}$ & $\mathbf{0 . 0 4 8}$ & $\mathbf{0 . 0 8 1}$ & $\mathbf{0 . 1 1 8}$ \\
\hline
\end{tabular}

iThe $\mathrm{F}$ tests should be used only for descriptive purposes because the clusters have been chosen to maximize the differences among cases in different clusters. The observed significance levels are not corrected for this and thus cannot be interpreted as tests of the hypothesis that the cluster means are equal.

${ }^{i i} C R I T E R I A: C 0=$ Intermediate target; $C 1=G D P p / c ; C 2=$ Inflation; $C 3=$ External debt stocks; $C 4=F C$ loans; $C 5 a=P L C B I ; C 5 b=C B G C M P ; C 5 c=C B T A ; C 6=$ Domestic credit to private sector; $C 7=$ Inter reserves; $C 8=$ Lending interest rate; $C 9=$ Trade openness $(\% G D P) ; C 10=$ Government budget deficit (expressed negatively); C11=Capital openness index.

Table 2: ANOVA test for all criteria of the non-hierarchical k-means cluster method

In the second step, indicators that proved not to be significant in first clustering and that were significant in [17] were taken into analysis. Results are presented in Tables 3 and 4. 


\begin{tabular}{|c|c|c|}
\hline Years & Clusters & $\begin{array}{l}\text { Number of countries with } \\
\text { appropriate intermediate target: }\end{array}$ \\
\hline \multirow{4}{*}{ 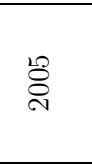 } & \multirow{2}{*}{$\begin{array}{l}\text { Cluster 1: Albania, Bosnia, Bulgaria, Croatia, } \\
\text { Estonia, Hungary, Latvia, Lithuania, Romania }\end{array}$} & -inflation targeting (2) \\
\hline & & -exchange rate targeting (7) \\
\hline & \multirow{2}{*}{$\begin{array}{l}\text { Cluster 2: Czech Republic, Macedonia, } \\
\text { Moldova, Poland, Turkey }\end{array}$} & -inflation targeting (3) \\
\hline & & -exchange rate targeting (2) \\
\hline \multirow{4}{*}{$\stackrel{\overbrace{}}{\circ}$} & \multirow{2}{*}{$\begin{array}{l}\text { Cluster 1: Albania, Bosnia, Bulgaria, Croatia, } \\
\text { Estonia, Hungary, Latvia, Lithuania, Macedonia }\end{array}$} & -inflation targeting (1) \\
\hline & & -exchange rate targeting (8) \\
\hline & \multirow{2}{*}{$\begin{array}{l}\text { Cluster 2: Czech Republic, Moldova, Poland, } \\
\text { Romania, Turkey }\end{array}$} & -inflation targeting (5) \\
\hline & & -exchange rate targeting $(0)$ \\
\hline \multirow{4}{*}{ 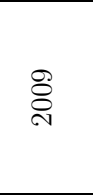 } & \multirow{2}{*}{$\begin{array}{l}\text { Cluster 1: Albania, Bosnia, Bulgaria, Croatia, } \\
\text { Estonia, Hungary, Latvia, Lithuania, Macedonia, } \\
\text { Romania }\end{array}$} & -inflation targeting (3) \\
\hline & & -exchange rate targeting (7) \\
\hline & \multirow{2}{*}{$\begin{array}{l}\text { Cluster 2: Czech Republic, Moldova, Poland, } \\
\text { Turkey }\end{array}$} & -inflation targeting (4) \\
\hline & & -exchange rate targeting $(0)$ \\
\hline \multirow{4}{*}{$\overrightarrow{\widetilde{\Omega}}$} & \multirow{2}{*}{$\begin{array}{l}\text { Cluster 1: Albania, Bosnia, Bulgaria, Croatia, } \\
\text { Estonia, Hungary, Latvia, Lithuania, Romania }\end{array}$} & -inflation targeting (3) \\
\hline & & -exchange rate targeting (6) \\
\hline & \multirow{2}{*}{$\begin{array}{l}\text { Cluster 2: Czech Republic, Macedonia, } \\
\text { Moldova, Poland, Turkey }\end{array}$} & -inflation targeting (4) \\
\hline & & -exchange rate targeting (1) \\
\hline
\end{tabular}

Table 3: Classification of countries using the non-hierarchical k-means cluster method according to 4 selected criteria

For all selected years, cluster 1 mainly comprises countries with exchange rate targeting, while inflation targeting countries prevail in cluster 2. This is in line with the expected results and previous research. In Table 4, bolded p-values show that foreign currency denominated loans and two forms of central bank independence (CBTA in each year and CBGCMP in three years) contribute to the difference between clusters. PLCBI proved insignificant. This means that only characteristics that really matter when the intermediate target is taken into account are foreign currency denominated loans, CBTA and CBGCMP.

\begin{tabular}{|c|c|c|c|c|}
\hline \multirow{2}{*}{ Criteria $^{\text {ii }}$} & \multicolumn{4}{|c|}{ F test ${ }^{\mathrm{i}} \mathrm{p}$-value } \\
\hline & 2005 & 2007 & 2009 & 2011 \\
\hline $\mathrm{C} 4$ & $<0.001$ & $<0.001$ & $<0.001$ & $<0.001$ \\
\hline $\mathrm{C} 5 \mathrm{a}$ & 0.965 & 0.777 & 0.574 & 0.965 \\
\hline $\mathrm{C} 5 \mathrm{~b}$ & 0.114 & 0.315 & 0.102 & 0.114 \\
\hline $\mathrm{C} 5 \mathrm{c}$ & 0.058 & 0.014 & 0.043 & 0.058 \\
\hline
\end{tabular}

$\mathrm{i}_{\text {The }} \mathrm{F}$ tests should be used only for descriptive purposes because the clusters have been chosen to maximize the differences among cases in different clusters. The observed significance levels are not corrected for this and thus cannot be interpreted as tests of the hypothesis that the cluster means are equal.

${ }^{\text {ii }}$ CRITERIA: $C 4=F C$ loans; $C 5 a=P L C B I ; C 5 b=C B G C M P ; C 5 c=C B T A$

Table 4: ANOVA test for 4 selected criteria of the non-hierarchical $k$-means cluster method 


\subsubsection{Multicriteria method - PROMETHEE method}

The PROMETHEE method is appropriate to treat the multicriteria problem of the following type:

$$
\operatorname{Max}\left\{f_{1}(a), \ldots, f_{n}(a) \mid a \in K\right\},
$$

where $K$ is a finite set of possible actions (here countries), and $f_{j}(a)$, where $j=1, \ldots, n$ are $n$ criteria to be maximized. For each action, $f_{j}(a)$ is an evaluation of this action. When we compare two actions, $a, b \in K$, we must be able to express the result of this comparison in terms of preference. Therefore, we consider a preference function $P$ :

$$
P: K \times K \rightarrow[0,1]
$$

representing the intensity of action $a$ with regard to action $b$. In practice, this preference function will be a function of the difference between the two evaluations $d=f(a)-f(b)$, and it is monotonically increasing. Six possible types (usual (1), U-shape (2), V-shape (3), level (4), linear (5) and Gaussian (6)) of this preference function are proposed to the decision maker [5], [6]. The effective choice is made interactively by the decision maker and the analyst according to their feeling of the intensities of preference. For all functions (1)(5), zero, one, or two parameters have to be fixed: $q$ is a threshold defining an indifference area, and $p$ is a threshold defining a strict preference area. For Gaussian function (6), $s$ is a parameter the value of which lies in a weak preference area (between minimum and maximum) [5], [6].

Now, we can define a preference index:

$$
\Pi(a, b)=\frac{\sum_{j=1}^{n} w_{j} P_{j}(a, b)}{\sum_{j=1}^{n} w_{j}},
$$

where $w_{j}$ are weights associated with each criteria.

Finally, for every $a \in K$, let us consider the following two outranking flows:

- leaving flow:

$$
\phi^{+}(a)=\sum_{b \in K} \Pi(a, b)
$$

- entering flow:

$$
\phi^{-}(a)=\sum_{b \in K} \Pi(b, a)
$$

The leaving flow $\phi^{+}$is the measure of the outranking character of $a$ (indicates how $a$ dominates all other actions of $K$ ). Symmetrically, the entering flow $\phi^{-}$ gives the outranked character of $a$ (indicates how $a$ is dominated by all other actions). The action is better if the leaving flow is higher and the entering flow 
is lower. The PROMETHEE I gives a partial reordering of the set of actions in which some actions are comparable, while some others are not. When the decision maker requests the complete ranking, the net outranking flow may be considered:

$$
\phi(a)=\phi^{+}(a)-\phi^{-}(a)
$$

The higher the net flow, the better the action. All the actions of $K$ are now completely ranked (PROMETHEE II).

For each criterion, one of the six offered preference function types and its thresholds has been chosen. In this way, the problem was completely prepared for the implementation of the PROMETHEE as an appropriate method for such multi-criteria and relatively weakly structured problem. Its advantages lie in the possibility to define indifference and preference thresholds that have the real economic importance.

The choice of the function types, and its thresholds, was carried out taking into account the criteria of impartiality, so that the weight of each criterion is equal and equals 9, except for GDP $\mathrm{p} / \mathrm{c}$ which, based on the results of the classification for each year, shows a significant contribution to the difference between the clusters formed. Therefore, the weight for GDP $\mathrm{p} / \mathrm{c}$ is 10 . Criteria PLCB, CBGCMP and CBTA related to central bank independence, and each of them has a weight of three. This is shown in Table 5. Linear function (5) was selected for the inflation criterion with thresholds 2 and 6 (in accordance with the inflation rate in the economies). The selected function type for all other criteria is Gaussian function (6) with appropriate parameter $s$. In this way, an unbiased analysis is ensured in accordance with the original numerical values. The final ranking is obtained by cumulating mutual comparisons of alternative pairs, according to all criteria, into final leaving and entering flows, i.e., the final rank of alternatives. The group of alternatives consists of 14 countries which are compared according to 11 previously observed criteria (central bank independence is presented with three criteria - PLCB, CBGCMP and CBTA).

\begin{tabular}{|l|c|c|c|c|c|c|c|c|c|c|c|c|c|}
\hline CRITERIA $^{\mathrm{i}}$ & $\mathrm{C} 1$ & $\mathrm{C} 2$ & $\mathrm{C} 3$ & $\mathrm{C} 4$ & $\mathrm{C} 5 \mathrm{a}$ & $\mathrm{C} 5 \mathrm{~b}$ & $\mathrm{C} 5 \mathrm{c}$ & $\mathrm{C} 6$ & $\mathrm{C} 7$ & $\mathrm{C} 8$ & $\mathrm{C} 9$ & C10 & C11 \\
\hline Min/Max & $\max$ & $\min$ & $\min$ & $\min$ & $\max$ & $\max$ & $\max$ & $\max$ & $\max$ & $\min$ & $\max$ & $\max$ & $\max$ \\
\hline Type & 6 & 5 & 6 & 6 & 6 & 6 & 6 & 6 & 6 & 6 & 6 & 6 & 6 \\
\hline Weight & 10 & 9 & 9 & 9 & 3 & 3 & 3 & 9 & 9 & 9 & 9 & 9 & 9 \\
\hline
\end{tabular}

${ }^{\mathbf{i}}$ CRITERIA: C1=GDP p/c; C2=Inflation; C3=External debt stocks; $C 4=F C$ loans; $C 5 a=P L C B I ;$

$C 5 b=C B G C M P ; C 5 c=C B T A ; C 6=$ Domestic credit to private sector; $C 7=$ Inter reserves; $C 8=$ Lending interest rate; $C 9=$ Trade openness (\%GDP); C10=Government budget deficit (expressed negatively); C11=Capital openness index.

Table 5: Types and weights of all criteria in 2005 - 2011 
The results of ranking are presented in Table 6. As can be seen, neither group of countries dominates the ranking considering the intermediate target. However, as the crisis emerged (2009) ranking of inflation targeting countries generally decreased, but after the crisis (2011), ranking is the same as before, crisis (2007). Therefore, neither do we find any significant difference in general economic performance considering the choice of the intermediate target nor the difference in performance in the period before and after the crisis. This means that some other characteristics (for example, EU membership, historical aspects, previous economic performance, capital abundance, infrastructure, bureaucracy, etc.) and not the intermediate target, affect macroeconomic and financial performance of CEE countries.

\begin{tabular}{|c|c|c|c|c|c|c|c|c|c|c|c|c|}
\hline \multirow{2}{*}{ 育 } & \multicolumn{3}{|c|}{2005} & \multicolumn{3}{|c|}{2007} & \multicolumn{3}{|c|}{2009} & \multicolumn{3}{|c|}{2011} \\
\hline & $\vec{E}$ & ACTION & PHI & $\vec{E}$ & ACTION & PHI & $\vec{E}$ & ACTION & PHI & $\vec{E}$ & ACTION & PHI \\
\hline 1. & 0 & Czech R. & 0.15 & 0 & Czech R. & 0.17 & 0 & Czech R. & 0.16 & 0 & Czech R. & 0.17 \\
\hline 2. & 0 & Poland & 0.07 & 0 & Poland & 0.09 & 1 & Estonia & 0.09 & 0 & Poland & 0.09 \\
\hline 3. & 1 & Estonia & 0.06 & 1 & Croatia & 0.07 & 1 & Croatia & 0.04 & 1 & Croatia & 0.07 \\
\hline 4. & 1 & Lithuania & 0.06 & 1 & Estonia & 0.04 & 0 & Poland & 0.03 & 1 & Estonia & 0.04 \\
\hline 5. & 1 & Hungary & 0.05 & 1 & Lithuania & 0.04 & 1 & Bulgaria & 0.01 & 1 & Lithuania & 0.04 \\
\hline 6. & 1 & Croatia & 0.02 & 1 & Bosnia & 0.02 & 1 & Macedon. & 0.01 & 1 & Bosnia & 0.02 \\
\hline 7. & 1 & Macedon. & 0.00 & 0 & Romania & -0.00 & 1 & Bosnia & -0.01 & 0 & Romania & -0.00 \\
\hline 8. & 1 & Bulgaria & 0.00 & 1 & Macedon. & -0.01 & 1 & Lithuania & -0.01 & 1 & Macedon. & -0.01 \\
\hline 9. & 1 & Bosnia & -0.02 & 0 & Albania & -0.04 & 0 & Turkey & -0.02 & 0 & Albania & -0.04 \\
\hline 10. & 1 & Latvia & -0.02 & 0 & Turkey & -0.04 & 0 & Hungary & -0.03 & 0 & Turkey & -0.04 \\
\hline 11. & 0 & Albania & -0.04 & 1 & Hungary & -0.04 & 0 & Albania & -0.05 & 0 & Hungary & -0.04 \\
\hline 12. & 1 & Turkey & -0.05 & 1 & Bulgaria & -0.04 & 0 & Romania & -0.06 & 1 & Bulgaria & -0.04 \\
\hline 13. & 0 & Romania & -0.12 & 1 & Latvia & -0.06 & 0 & Moldova & -0.07 & 1 & Latvia & -0.06 \\
\hline 14. & 0 & Moldova & -0.17 & 0 & Moldova & -0.18 & 1 & Latvia & -0.07 & 0 & Moldova & -0.18 \\
\hline
\end{tabular}

Table 6: PROMETHEE II complete ranking in 2005, 200\%, 2009 and 2011 according to selected indicators

Finally, binary logistic regressions were estimated to find dependence of countries' intermediate targeting and values of selected economic variables. A significant odds ratio would show if a country with exchange rate targeting (or inflation targeting) has a probability for higher appropriate criteria. Parameters were evaluated by iterative maximum-likelihood estimation (MLE). All models indicate that there are no significant parameters, i.e., there are no probabilities for higher or lower values of economic variables in some country if the country uses inflation targeting or exchange rate targeting. 


\section{Conclusion}

Intermediate target serves as a nominal anchor for monetary policy and tends to resolve the problem of time-lag in conducting monetary policy by which central bank accomplishes and maintains its ultimate goal of monetary policy. The practical choice of the intermediate target in CEE countries refers to inflation and exchange rate targeting. The aim of this paper was to cluster countries according to their choice of the intermediate target and selected variables. First clustering, that took into consideration all variables, did not divide countries considering the choice of the intermediate target. Variables economic development (GDP $\mathrm{p} / \mathrm{c}$ ), domestic credit to the private sector and the capital openness index contributed to the difference between clusters in each selected year. In second clustering, variables that were not proved significant in any year in first clustering and that were significant in previous research were taken into analyses. The results show that foreign currency denominated loans, Transparency and Accountability of the central bank and Governance and Conduct of Monetary Policy contribute to difference between clusters. This means that countries that have inflation targeting and countries that have exchange rate targeting significantly differ when these indicators are taken into account.

Moreover, countries were ranked with respect to selected variables using the PROMETHEE method. However, no significant difference in general economic performance considering the choice of the intermediate target was found. In contrast to other relevant characteristics mentioned above, the choice of the intermediate target does not affect macroeconomic and financial performance of CEE countries. Moreover, even inflation targeting countries slowly decrease in ranking as the crisis emerges (2009); in 2011, the ranking is the same as before the crisis (2007). Therefore, we do not find any significant changes in ranking of countries considering the overall economic performance in the period before and after the financial crisis.

Also, binary logistic regressions showed that there are no significant parameters, i.e., there are no probabilities for higher or lower values of economic variables in some country if the country uses inflation or exchange rate targeting. Generally, in line with expected results and previous research, the choice of intermediate targets, i.e., inflation targeting is significantly interrelated with lower FC loans to total loans and higher Transparency and Accountability (CBTA) and vice versa for exchange rate targeting. 
CEE countries

\section{References}

[1] Anderberg, Michael R. (1973). Cluster Analysis for Applications. New York: Academic Press.

[2] Arestis, P. and Sawyer, M. (2008). New consensus macroeconomics and inflation targeting: Keynesian critique. Economia e sociedade, Campinas, Volume 17, Numero especial, 631-655.

[3] Beblavy, M. (2007). Monetary Policy in Central Europe. Routledge Press. USA and Canada.

[4] Bofinger, P. (2001). Monetary Policy: Goals, Institutions, Strategies, and Instruments. Oxford Press.

[5] Brans, J. P. and Vincke P. (1985). A preference ranking organisation method for MCDM. Management Science, 31(6), 647-656.

[6] Brans, J. P. and Mareschal B. (1989). The PROMETHEE methods for MCDM, the PROMCALC, GAIA and Bankadviser Software. Working Paper STOO/224, Vrije Universiteit Brussel.

[7] Chinn, M. D., Ito, H. (2007). A New Measure of Financial Openness. Portland State University.

[8] Dumiter, F. C. (2009). Measuring Central Bank independence and inflation targeting in developed and developing countries. West University of Timisoara, Romania, Faculty of Economics and Business Administration Timisoara Journal of Economics, 2(2), 83-100.

[9] Herrero, A. G., del Rio, P. (2003). Financial stability and the design of monetary policy. Banco de Espana Working Paper No. 0315.

[10] Houben, A. C. F. J. (2000.). The Evolution of Monetary Policy Strategies in Europe. Kluwer Academic Publishers. Boston.

[11] Mishkin, F. S. (2000a). From Monetary Targeting to Inflation Targeting: Lessons from the Industrialized Countries. Conference Stabilization and Monetary Policy: The International Experience.

[12] Mishkin, F. S. (2001b). Monetary policy strategies for emerging market countries: Case studies from Latin America. Conference "Current Issues in Emerging Market Economie", Dubrovnik, Croatia.

[13] Mohanty, M. S., Turner, P. (2008). Monetary policy transmission in emerging market economies: What is new? in BIS Papers, No. 35 Transmission mechanism for monetary policy in emerging market economies, 1-61.

[14] Pivac S., Pečarić M. (2010). Multivariate and multicriterial foreign debt analysis of the selected transition countries. Croatian Operational Research Review, 1, 124-137.

[15] Squeff, G. C., Oreiro, J., L., de Paula, L. F. (2010). A Post-Keynesian proposal for a flexible institutional arrangement of inflation targeting regime in emerging economies. University of Brasilia, Department of Economics Working Paper No. 336.

[16] Tomić-Plazibat N., Aljinović Z. and Pivac S. (2010). Risk assessment of transition economies by multivariate and multicriteria approaches. Panoeconomicus, 57(3), 283-302. 
[17] Visković, J. (2012). The determinants of intermediate target's choice of monetary policy strategy: The case of CEE countries. The Business Review, Cambridge, 19(2), 296-303. 